\title{
Inter-Treaty Cooperation, Biodiversity Conservation and the Trade in Endangered Species
}

\section{Richard Caddell}

In recent years, concerns have been raised over the ability of multilateral environmental agreements to effectively coordinate their policies and activities on issues of mutual interest. This article examines the current initiatives pursued by the 1973 Convention on International Trade in Endangered Species (CITES) to synergize its activities for the conservation of biodiversity with allied regimes. It examines cooperative policies undertaken alongside the two key biodiversity treaties with which CITES operates most closely namely the 1992 Convention on Biological Diversity and the 1979 Convention on the Conservation of Migratory Species of Wild Animals. The article outlines broad thematic and species-specific interactions, suggesting that while there is considerable scope to develop cooperative working practices, a degree of caution is appropriate as to the current level of priority placed upon synergies between these regimes as a solution to operative challenges.

\section{INTRODUCTION}

In the forty years since the conclusion of the 1973 Convention on International Trade in Endangered Species of Wild Fauna and Flora (CITES), ${ }^{1}$ multilateral regimes with an application to threatened biodiversity have steadily proliferated. Although this development ought to be considered highly encouraging, indicative of a maturation of international environmental law generally and a clear global interest in the plight of imperilled species specifically, concerns have nonetheless arisen over the practical coordination of this sprawling network of actors and instruments. In particular, reservations have long been expressed over the perils of so-called 'treaty congestion', ${ }^{2}$ where poor inter-regime cooperation may generate competing and potentially conflicting conservation priorities, alongside administrative and managerial duplication, inconsistencies and wastage.

\footnotetext{
${ }^{1}$ Convention on International Trade in Endangered Species (Washington, DC, 3 March 1973; in force 1 July 1975) ('CITES').

${ }^{2}$ See especially E. Brown Weiss, 'International Environmental Law: Contemporary Issues and The Emergence of a New World Order', 81:3 Georgetown Law Journal (1993), 675; and B.L. Hicks, 'Treaty Congestion in International Environmental Law: The Need for Greater International Coordination', 32:5 University of Richmond Law Review (1999), 1643.
}

The continued preference for autonomous multilateral environmental agreements (MEAs) as the modern regulatory model of choice ${ }^{3}$ has rendered international efforts to regulate particular species a deceptively complicated and, arguably, counter-productive affair. ${ }^{4}$ Increasingly, a core task of multilateral biodiversity management has involved marshalling the interrelationship between MEAs to facilitate uniform and complementary conservation strategies. ${ }^{5}$ To take a practical example, the regulation of a single species such as the iconic blue whale (Balaenoptera musculus) currently categorized as 'endangered', ${ }^{6}$ requires the coordination of a disparate mosaic of multilateral bodies. As a (previously) commercially hunted species it is governed by the 1946 International Convention for the Regulation of Whaling (ICRW) ${ }^{7}$ and is thereby subject to managerial oversight by the International Whaling Commission (IWC). Additionally, as a migratory species, blue whales have long been listed on the Appendices of the Convention on the 1979 Conservation of Migratory Species of Wild Animals (CMS) ${ }^{8}$ and are subject to particular measures to address impediments to migration and rehabilitate wild stocks and habitat ranges. As a species considered vulnerable to the adverse impacts of international trade it has also been listed on the Appendices to CITES and is thereby subject to protective trade policies. More recently, the

\footnotetext{
${ }^{3}$ On the emergence of such regimes and the legal issues raised thereby, see R.R. Churchill and G. Ulfstein, 'Autonomous Institutional Arrangements in Multilateral Environmental Agreements: A Littlenoticed Phenomenon in International Law', 94:4 American Journal of International Law (2000), 623.

${ }^{4}$ For a searching critique of the fragmented status quo, see $A$. Jóhannsdóttir, I. Cresswell and P. Bridgewater, 'The Current Framework for International Governance of Biodiversity: Is it Doing More Harm than Good?', 19:2 Review of European Community and International Environmental Law (2010), 139. For a more cautiously optimistic prognosis of the current status of inter-treaty coordination, see R. Caddell, 'The Integration of Multilateral Environmental Agreements: Lessons from the Biodiversity-related Conventions', 22:1 Yearbook of International Environmental Law (2011), 37.

${ }^{5}$ See R. Caddell, n. 4 above, at 39-48.

${ }^{6}$ As designated on the current version of the International Union for Conservation of Nature (IUCN) Red List of Threatened Species. See $<$ http://www.iucnredlist.org $>$.

${ }^{7}$ International Convention for the Regulation of Whaling (Washington, DC, 2 December 1946; in force 11 October 1948).

${ }^{8}$ Convention on the Conservation of Migratory Species of Wild Animals (Bonn, 23 June 1979; in force 1 November 1983) ('CMS').
} 
1992 Convention on Biological Diversity (CBD) ${ }^{9}$ has substantially expanded its marine programme, with further regulatory implications for blue whales. In addition to these prominent global instruments, regional agreements will also be highly relevant, including the Antarctic regime ${ }^{10}$ and CMS subsidiaries addressing southern Europe ${ }^{11}$ and the Pacific region. ${ }^{12}$ Furthermore, blue whales face particular conservation threats that fall under the purview of other regimes. By-catches are considered to be an especially pernicious hazard to cetaceans; ${ }^{13}$ managerial coordination with a plethora of fisheries management organizations is therefore a vital conservation strategy. Likewise, engagement with a multitude of pollution control bodies will be required to improve habitat quality. Meanwhile, the management of international shipping activities - such as the mitigation of anthropogenic noise ${ }^{14}$ and the proactive reduction of vessel-strike mortality ${ }^{15}$ - will also play a key role, necessitating a mutually supportive working relationship with the International Maritime Organization (IMO). Multilateral efforts to actively conserve an individual species - whether marine, terrestrial or avian - accordingly involve a significant operational undertaking.

Against this backdrop, and with CITES presently exercising responsibility over almost 35,000 individual species of flora and fauna, effective coordination with allied MEAs constitutes a significant institutional priority. Indeed, at the recent Rio+20 Conference in 2012, the international community formally acknowledged

\footnotetext{
${ }^{9}$ Convention on Biological Diversity (Rio de Janeiro, 5 June 1992; in force 29 December 1993) ('CBD').

${ }^{10}$ Convention for the Conservation of Antarctic Marine Living Resources (Canberra, 20 May 1980; in force 7 April 1982). Under Article VI of the Convention, regulatory authority over Antarctic whale stocks is expressly deferred to the IWC, although the Commission for the Conservation of Antarctic Marine Living Resources (CCAMLR) does exercise oversight over krill, the staple prey of the blue whale. CITES interests in Antarctic whales have been increasingly engaged in recent years. See P.H. Sand, 'Japan's "Research Whaling" in the Antarctic Southern Ocean and the North Pacific Ocean in the Face of the Endangered Species Convention (CITES)', 17:1 Review of European Community and International Environmental Law (2008), 56.

${ }^{11}$ Agreement on the Conservation of Cetaceans of the Black Sea, Mediterranean Sea and Contiguous Atlantic Area (Monaco, 24 November 1996; in force 1 June 2001) ('ACCOBAMS').

${ }^{12}$ Memorandum of Understanding for the Conservation of Cetaceans and Their Habitats in the Pacific Islands Region (Noumea, 15 September 2006; in force 15 September 2006).

${ }^{13}$ A.J. Reid, 'The Looming Crisis: Interactions between Marine Mammals and Fisheries', 89:3 Journal of Mammalogy (2008), 541.

${ }^{14}$ On this issue, see A. Gillespie, 'Noise Pollution, The Oceans and the Limits of International Law', 21:1 Yearbook of International Environmental Law (2010), 114.

${ }^{15}$ On current International Maritime Organization (IMO) policies in this regard, see R. Caddell, 'Shipping and the Conservation of Marine Biodiversity: Legal Responses to Vessel-strikes of Marine Mammals', in: R. Caddell and D.R. Thomas (eds.), Shipping, Law and the Marine Environment in the Twenty-first Century (Lawtext, 2013), 86, at 95-114.
}

the important role of the Convention on International Trade in Endangered Species of Wild Fauna and Flora, an international agreement that stands at the intersection between trade, the environment and development, promotes the conservation and sustainable use of biodiversity, should contribute to tangible benefits for local people, and ensures that no species entering into international trade is threatened with extinction....In this regard, we emphasize the importance of effective international cooperation among relevant multilateral environmental agreements and international organizations. ${ }^{16}$

Institutional synergies are frequently championed as a means of improving the performance of MEAs, yet the operational effectiveness of inter-treaty collaborations remains decidedly under-assessed. Although prosaic, the integrative practices of such bodies nonetheless remain quietly significant, ${ }^{17}$ and offer important lessons in modern regime interaction..$^{18}$ Under pressure to achieve substantially more with considerably less, and with performance and wastage fastidiously audited, MEAs are becoming increasingly obliged to integrate and align their activities further - a trend that has implications both for individual regimes and for the future of international environmental governance. ${ }^{19}$ This article accordingly examines the current state of cooperation between CITES and two leading MEAs for the conservation of biodiversity namely the CBD and the CMS. It first appraises the cooperative models adopted by CITES in addressing inter-treaty liaison, before considering the thematic and executive synergies developed with the CBD to address overlapping issues of concern. Finally, it evaluates collaborative activities with the CMS, with which CITES arguably maintains the greatest scope for interaction due to the number of overlapping species regulated under the umbrella of both regimes.

${ }^{16}$ The Future We Want (UN Doc. A/RES/66/288, 11 September 2012), at paragraph 203 (emphasis added).

${ }^{17}$ For an illuminating account of the legal difficulties concerning the operational powers of MEA institutions, see B.H. Desai, Multilateral Environmental Agreements: Legal Status of the Secretariats (Cambridge University Press, 2011), at 133-170.

${ }^{18}$ On the importance of such case studies, see M.A. Young, 'Regime Interaction in Creating, Implementing and Enforcing International Law', in: M.A. Young, Regime Interaction in International Law: Facing Fragmentation (Cambridge University Press, 2012), 85.

${ }^{19}$ Following its 'Future Shape' deliberations the CMS considers that closer coordination with other regimes and resource sharing will be vital to its future activities, while the amalgamation of the core biodiversity treaties within the CBD is also advocated. See A. Jóhannsdóttir, I. Cresswell and P. Bridgewater, n. 4 above, at 147-149. The so-called 'chemical cluster' of treaties is undertaking a process of administrative and executive fusion, although this remains at an early stage. See R. Caddell, n. 4 above, at 60-61. Commentators have nonetheless warned that linkages are not a panacea against the current challenges facing biodiversity MEAs. See A. Long, 'Developing Linkages to Preserve Biodiversity', 21:1 Yearbook of International Environmental Law (2010), 41. 


\section{CITES AND THE SCOPE FOR INTER-TREATY COOPERATION}

The elaboration of a unique regime straddling the boundaries of international trade and environmental protection was initially mandated by the International Union for Conservation of Nature (IUCN) in 1963. Further impetus towards this broad objective was generated at the 1972 United Nations Conference on the Human Environment (UNCHE), where the Stockholm Action Plan called for the development of a convention 'on export, import and transit of certain species of wild animals and wild plants'. ${ }^{20}$ Concluded in 1973, CITES has since become one of the most widely-ratified MEAs to date, with 178 current parties. ${ }^{21}$

CITES is a member of the so-called 'Biodiversityrelated Conventions' - a cluster of six core treaties with an application to global nature conservation. ${ }^{22}$ Unlike many of these regimes, however, CITES represents a more specialized forum for biodiversity management, maintaining an exclusive focus on international trade. It is therefore not designed to provide a holistic framework to address the myriad threats to vulnerable species. Nevertheless, there is copious recognition within its policies towards individual species that these broad themes are not mutually exclusive and that trade restrictions may become necessary due in large part to wider environmental factors. Accordingly, as noted below, the CITES parties and institutions maintain a keen interest in regimes that seek to provide a broader habitat-based approach to species management.

Thematically, CITES applies solely to 'international' trade; internal trade is accordingly a matter exclusively for domestic law or, alternatively, for a union or regional trade agreement affecting customs boundaries. ${ }^{23}$ As observed below, this restriction in scope has had an influence on collaborative practices with

${ }^{20}$ Stockholm Action Plan, in: Report of the United Nations Conference on the Human Environment (UN Doc. A/CONF.48/14/Rev.1, 16 June 1972), Recommendation 99.

${ }^{21}$ As of 12 August 2013. Lebanon is the most recent member, acceding on 26 May 2013

${ }_{22}$ Alongside the CBD and CMS, the cluster further includes the Convention on Wetlands of International Importance, especially as Waterfowl Habitat 1971 (Ramsar, 2 February 1971; in force 21 December 1975), the Convention Concerning the Protection of the World Cultural and Natural Heritage 1972 (Paris, 23 November 1972; in force 17 December 1975) and the International Treaty on Plant Genetic Resources for Food and Agriculture 2002 (Rome, 6 June 2002; in force 29 June 2004).

${ }^{23}$ CITES, n. 1 above, Article XIV.3. In practice, this latter position will apply only to Member States of the European Union (EU), which implements the provisions of CITES within the common market under Regulation 338/97/EC of 3 March 1997 on the Protection of Species of Wild Fauna and Flora by Regulating Trade Therein, [1997] OJ L61/1. The EU has long sought to accede to CITES, but the 1983 Gaborone amendment to the convention permitting this has not yet entered into force - having been effectively blocked by the requirement of acceptance by at least 54 its members that were full parties particular regimes involving common parties within which the trade in mutual species is strictly municipal.

Like many other nature conservation regimes, CITES operates a listing approach, classifying species according to the exigency of their conservation status and prescribing a sliding scale of commitments accordingly. Under Article II.1, Appendix I includes all species threatened with extinction which are or may be threatened by trade. Trade in these species is subject to 'particularly strict regulation in order not to endanger further their survival and must only be authorised in exceptional circumstances'. Appendix II addresses all species which 'although not necessarily threatened with extinction may become so unless trade in specimens of such species is subject to strict regulation in order to avoid utilisation incompatible with their survival'. ${ }^{24}$ Additionally, species may be listed in Appendix II if they do not fulfil this criterion, but nevertheless require protection in order to bring international trade in such species under effective control. Under Article II.3, parties may apply to list additional species subject to national protection that require the cooperation of other parties to restrict trade; such species are so designated on Appendix III of the convention. With a vast array of species, sub-species and populations having been listed on these Appendices over the past forty years, there is accordingly a strong basis for CITES to interact with a multitude of multilateral actors in pursuing mutual objectives and conservation priorities.

On a practical level, such interaction is undertaken through the operative institutions of CITES. Upon inauguration, most MEAs adopt a broadly similar institutional structure, typically establishing a Conference of the Parties (COP) as a decision-making body, a Secretariat as an administrative hub and permanent focal point, alongside a specialist advisory group providing technical advice to help frame operational priorities. The general similarity between these structures provides obvious points of interaction between MEAs. In the case of CITES, the COP is charged with reviewing the implementation of the convention, with particular responsibility for considering amendments to the Appendices and to improving its effectiveness, ${ }^{25}$ which has included the adoption of resolutions and decisions to promote collaborative activities. The COP has also established separate specialist committees to provide scientific and expert technical advice on plants and animals respectively. The Plants and Animals Committees have also acted as visible points of contact for treaty interaction. Alongside a Standing Committee, which advises the COP on an inter-sessional basis,

at the material time. The EU institutions have nonetheless bypassed this tactical obstruction by formulating a pre-agreed collective position prior to major CITES meetings.

${ }^{24}$ CITES, n.1 above, Article II.2.

25 Ibid., Article XI. 
CITES maintains an active Secretariat which has played a key role in promoting the convention and its work to its MEA counterparts. Finally, CITES places a strong emphasis upon the establishment of national bodies to implement the convention. Parties are required to designate national Management Authorities, which are charged with granting permits and certificates for the import and export of listed species, alongside Scientific Authorities to advise on the merits of issuing such permits. ${ }^{26}$ These bodies have also played an important role in promoting coherence between international commitments at a national level.

Legally, the projected relationship between CITES and allied multilateral bodies is addressed to a certain degree within the text of the convention itself. Some pause for caution is, however, appropriate in this respect since the rather idiosyncratic wording of these provisions has had occasional complications for the treaty's external relations. Poor drafting of such clauses in MEAs is by no means confined to CITES. ${ }^{27}$ However, its impact is compounded by a lack of overarching normative principles guiding treaties that are intended whether by design or implication - to work collaboratively. ${ }^{28}$ The effect of other international instruments on the convention is addressed in Article XIV. A rather orthodox conflict clause is advanced in Article XIV.2, proclaiming that CITES 'shall in no way' affect national obligations arising from international agreements relating to other aspects of trade, taking, possession or transport of specimens. This has created relatively little turbulence from the main treaties with which CITES interacts most frequently. As noted below, the CBD has generally sought the advice of CITES where trade and transportation matters are raised, while the CMS has either expressly advocated a close engagement with the convention on such issues or otherwise encouraged the parties to apply the lessons learned through the national implementation of CITES commitments in regulating trade in species to which CITES is not applicable.

Friction has arisen predominantly in the case of certain marine species, however, largely due to the application of Article XIV.4, which provides that:

\footnotetext{
${ }^{26}$ Ibid., Article IX.

${ }^{27}$ Article 22 of the CBD, n. 9 above, is perhaps the most notorious example of the genre, with an insistence upon its incompatibility with treaties that may 'cause a serious damage or threat to biodiversity' creating scope for difficulties in framing its relationship with allied regimes. See R. Caddell, n. 4 above, at 50-52. This may be particularly acute in the context of marine species. See R. Wolfrum and N. Matz, 'The Interplay of the United Nations Convention on the Law of the Sea and the Convention on Biological Diversity', 4:1 Max Planck Yearbook of United Nations Law (2000), 445.

${ }^{28}$ For an insightful appraisal of the limitations of international treaty law in this respect, see $\mathrm{H}$. van Asselt, 'Managing the Fragmentation of International Environmental Law: Forests at the Intersection of the Climate and Biodiversity Regimes', 44:4 New York University Journal of International Law and Politics (2011), 1205, at 1243-1255.
}

A State party to the present Convention, which is also a party to any other treaty, convention or international agreement which is in force at the time of the coming into force of the present Convention and under the provisions of which protection is afforded to marine species included in Appendix II, shall be relieved of the obligations imposed on it under the provisions of the present Convention with respect to trade in specimens of species included in Appendix II that are taken by ships registered in that State and in accordance with the provisions of such other treaty, convention or international agreement.

This provision raises considerable interpretive challenges. As Young outlines, it would seemingly address only those marine-related instruments that were in existence prior to the conclusion of CITES. ${ }^{29}$ Moreover, whether the limited number of fisheries treaties that survive from the pre-CITES era may be categorically viewed as advancing the 'protection' of marine species is a matter of some debate..$^{30}$ It is accordingly difficult to state definitively how this clause is intended to operate in practice.

Article XIV.4 has arguably provoked the greatest degree of unforeseen mischief in the context of commercial whaling. This has arisen primarily through the actions of mutual parties seeking to downgrade the protection afforded to whales under CITES in order to pressurize the continuing IWC moratorium on commercial hunting, instituted in 1982. The result has been the partial displacement of the debate over whale conservation - and its accompanying controversies - into CITES, much to the discomfort of its Secretariat. Potential conflicts between CITES and the ICRW were first considered within the IWC at the time of its conclusion..$^{31}$ Throughout the early years of the operation of CITES, the IWC was itself targeting trade concerns to deter so-called 'pirate whaling' and to prevent the emergence of unregulated markets for whale meat. ${ }^{32}$ Viewing

${ }^{29}$ M.A. Young, Trading Fish, Saving Fish: The Interaction between Regimes in International Law (Cambridge University Press, 2011), at 65-67.

${ }^{30}$ lbid., at 66-67.

${ }^{31}$ At the 25th Annual Meeting of the IWC, convened in 1973, the CITES Technical Committee drew attention to the possibility of 'conflict between decisions taken by the Commission on the taking of certain species of whales and action taken under the provisions of this convention on the capture of whales or trading in the products of such whales', while individual Commissioners were urged to communicate this issue to their governments in order to facilitate reservations to CITES on this basis. See IWC, Twenty-Third Report of the International Whaling Commission (IWC, 1975), at 33.

32 See IWC Resolution 1976-5, Resolution on Transfer of Vessels, Equipment and Assistance (25 June 1976); IWC Resolution 1977-8, Resolution on Prevention of Transfer of Whaling Vessels, etc. (24 June 1977); IWC Resolution on Importation of Whale Products from Non-IWC Member Countries and Resolution on Transfer of Whaling Equipment and Expertise, etc. (both Resolutions adopted at a rare Special Meeting of the IWC, 20 December 1978); IWC Resolution 1979-9; Resolution on Importation of Whale Products from, Export of Equipment to, and Prohibition of Whaling by Non-Member Countries (13 July 1979); IWC Resolution 1980-6, Resolution aimed at Discouraging Whaling Operations Outside IWC Regulations (26 July 1980). 
the new convention as a potential ally in this regard, in 1976 the IWC offered to act as the official advisor to CITES on cetaceans. ${ }^{33}$ Noting the desirability of using 'each international opportunity to stop the taking and to ban trade in those species and stocks of whales which receive total protection', CITES was in turn requested to 'take all possible measures' to support pertinent IWC restrictions. ${ }^{34}$

This invitation was swiftly accepted - and with unexpected consequences. Within its first decade of activity, CITES exerted an unexpected influence over the trajectory of conservation measures within the IWC. Having listed a number of whale species on its Appendices at a preliminary stage, ${ }^{35}$ at its second COP all species of cetaceans that had not been designated to Appendix I were listed on Appendix II. At the third COP, and having previously advocated the "maximum protection possible' for cetaceans listed in the Appendices, ${ }^{36}$ the CITES parties up-listed a number of species to Appendix I. Consequently, commercially exploited whales then qualified for a greater degree of protection under CITES than the ICRW. ${ }^{37}$ This development has been credited as a contributory factor to the introduction of the commercial moratorium by the IWC; ${ }^{38}$ having been 'outflanked' by CITES, ${ }^{39}$ pressure intensified within the Commission for stronger protective measures. In response to the adoption of the moratorium on commercial hunting under the ICRW, the remaining commercially harvested species of whales had been added to Appendix I of CITES at its fourth COP a year later a listing that was scheduled to enter into effect concurrently with the IWC restrictions. ${ }^{40}$

Maintaining this heightened degree of protection for whales subject to the IWC moratorium has long been a

\footnotetext{
${ }^{33}$ IWC, Twenty-sixth Report of the International Whaling Commission (IWC, 1978), at 23.

${ }^{34}$ Resolution to CITES, adopted at the Special Meeting of the IWC in 1978. Nevertheless, a degree of wariness remained towards the nascent CITES regime within the IWC at this juncture. See IWC, Twenty-eighth Report of the International Whaling Commission (IWC, $1980)$, at 5.

${ }^{35}$ In 1975, blue, humpback, grey, right and bowhead whales were listed on Appendix I, while in 1977 stocks of fin and sei whales were added to Appendix II. See A. Gillespie, Whaling Diplomacy: Defining Issues in International Environmental Law (Edward Elgar, 2005), 337. ${ }^{36}$ CITES Resolution Conf. 2.8, Introduction from the Sea (30 March 1979).

${ }^{37}$ See A. Gillespie, n. 35 above, 337.

${ }^{38}$ P.W. Birnie, International Regulation of Whaling: From Conservation of Whaling to Conservation of Whales and Regulation of Whalewatching (Oceana, 1985), 405. It should be observed that this was far from the only motivating factor, however, and that attempts to impose zero quotas on great whales pre-date the conclusion of CITES.

${ }^{39}$ A. D'Amato and S.K. Chopra, 'Whales: Their Emerging Right to Life', 85:1 American Journal of International Law (1991), 21, at 43. ${ }^{40}$ Under Article XV.1(c), amendments to the CITES Appendices ordinarily enter into effect ninety days subsequent to the COP at which the amendment was accepted. Accordingly, the decision to delay the entry into effect of these amendments represents a rare departure from CITES practice.
}

central feature of the interrelationship between CITES and the ICRW. This arrangement was largely harmonious until the ninth COP in 1994, at which point applications to down-list particular whale species from Appendix I were tabled for the first time. ${ }^{41}$ Such proposals have been consistently raised and defeated within CITES in subsequent COPs, accompanied by trenchant debate between the parties.$^{42}$ These developments have caused considerable unease both within the IWC, which has exhorted its members to refrain from agitation within alternative fora, ${ }^{43}$ and CITES, which in 2000 took the unusual step of formally complaining that the 'transfer of the IWC debate' was starting to 'polarize decision-making' in the trade convention. ${ }^{44}$ Such concerns were particularly acute at the fourteenth COP to CITES in 2007 which, by a quirk of the institutional calendar, was convened back-to-back with a decidedly attritional IWC Meeting. In response to further down-listing proposals, a decision was adopted by the COP, directed at the Animals Committee and stating that ' $[\mathrm{n}] \mathrm{o}$ periodic review of any great whale, including the fin whale, should occur while the moratorium by the International Whaling Commission is in place. ${ }^{45}$ This categorical undertaking accordingly nullifies any future down-listing proposals while the IWC moratorium on commercial harvesting remains operational, with CITES now seemingly closed as an avenue through which to undermine these restrictions.

With overlapping species rendering the phenomenon of 'regime-shifting' something of an occupational hazard for multilateral bodies - especially in a marine context, whereby States have proved adept at playing organizations off against each other ${ }^{46}$ - the relationship

\footnotetext{
${ }^{41}$ See K. Eldridge, 'Whale for Sale? New Developments in the Convention on International Trade in Endangered Species of Wild Fauna and Flora', 24:3 Georgia Journal of International and Comparative Law (1995), 549.

${ }^{42}$ C.P. Carlarne, 'Saving the Whales in the New Millennium: International Institutions, Recent Developments and the Future of International Whaling Policies', 24:1 Virginia Environmental Law Journal (2005), 1, at 24-28.

${ }^{43}$ IWC Resolution 1999-6, Resolution on Cooperation between the IWC and CITES (28 May 1999); IWC Resolution 2001-5, Resolution on Commercial Whaling (27 July 2001); IWC Resolution 2007-4, Resolution on CITES (31 May 2007).

${ }^{44}$ Letter from (then) Secretary-General Willem Wijnstekers to the IWC: reproduced in A. Gillespie, n. 35 above, at 340-341. These sentiments echo those expressed previously by Japan, urging the IWC to resolve this issues swiftly 'otherwise the scientific basis by which CITES has opted for operating will become frustrated'. See IWC, Forty-eighth Report of the International Whaling Commission (IWC, 1998), at 40.

${ }^{45}$ CITES Decision 14.81, Great Whales (15 June 2007). These restrictions seemingly apply only to the lethal exploitation of great whales: at the sixteenth COP the parties amended CITES Resolution Conf. 9.6, Trade in Readily Identifiable Parts and Derivatives (5 March 2013), to permit limited trade in ambergris and other lucrative products derived from sperm whale excretia.

${ }^{46}$ See J. Harrison, Making the Law of the Sea: A Study in the Development of International Law (Cambridge University Press, 2011), at 240-241.
} 
between CITES and the IWC represents a cautionary tale for the perils of forum shopping. ${ }^{47}$ Relations have improved in recent years, although doubts have been expressed whether the two organizations can co-exist harmoniously, given the heavy politicization of the whaling issue. ${ }^{4}$ For its part, CITES has repeatedly pledged support for a strong collaborative relationship with the IWC, ${ }^{49}$ which has in turn been reciprocated..$^{50}$ Pointedly, however, while acknowledging the scientific pre-eminence of the ICRW regime,,$^{51}$ CITES has consistently maintained that the trade in whale products 'cannot be controlled effectively by the IWC alone'.52 Obvious areas of mutual activity would include the enforcement of trade restrictions, which the IWC has targeted in isolation as a key aspect of future reforms, ${ }^{53}$ whereas CITES has extensive experience in establishing and operating DNA registries and in training customs officials. However, largely due to concerns over the limits of their respective remits, the development of a more coherent and coordinated programme of mutual activity between CITES and the IWC remains a seemingly distant prospect at present.

The difficulties experienced between CITES and the IWC highlight the utility of elaborating clear and mutually agreed lines of cooperation and activity between multilateral bodies. Increasingly, and echoing a trend set by the CBD, most MEAs have loosely formalized their external relations through a network of non-binding agreements, typically in the form of

\footnotetext{
${ }^{47}$ On this issue, see especially A. Gillespie, 'Forum Shopping in International Environmental Law: The IWC, CITES and the Management of Cetaceans', 33:1 Ocean Development and International Law (2002), 17.

${ }^{48}$ D.R. Rothwell and T. Stephens, The International Law of the Sea (Hart, 2010), at 472.

${ }^{49}$ CITES Resolution Conf. 2.7, Relationship with the International Whaling Commission (30 March 1979); CITES Resolution Conf. 3.13, Trade in Whale Products (8 March 1981); CITES Resolution Conf. 9.12, Illegal Trade in Whale Meat (18 November 1994); CITES Resolution Conf. 11.4, Conservation of Cetaceans, Trade in Cetacean Specimens and the Relationship with the International Whaling Commission (20 April 2000)

50 IWC Resolution 1994-7, Resolution on International Trade in Whale Meat and Products (27 May 1994); IWC Resolution 1995-6, Resolution on Improving Mechanisms to Prevent Illegal Trade in Whale Meat (2 June 1995); IWC Resolution 1996-3, Resolution on Improving Mechanisms to Restrict Trade and Prevent Illegal Trade in Whale Meat (28 June 1996); IWC Resolution 1999-6, n. 43 above; IWC Resolution 2007-4, n. 43 above.

${ }^{51}$ Most recently, CITES has recognized 'the IWC's Scientific Committee as the universally recognised international institution with international expertise to review and evaluate the status of the world's whale stocks'. See IWC Resolution 2007-4, n. 43 above.

${ }^{52}$ CITES Resolution Conf. 2.9, Trade in Certain Species and Stocks of Whales Protected by the International Whaling Commission from Commercial Whaling (30 March 1979); CITES Conf. Resolution 11.4, n. 49 above.

${ }^{53}$ IWC, Sixty-second Report of the International Whaling Commission (IWC, 2010), at 61.
}

Memoranda of Understanding (MOUs). ${ }^{54}$ This is perhaps the most tangible way in which secretariats fulfil their treaty-derived obligations to facilitate dialogue with allied bodies. The precise legal foundation for the conclusion of such instruments is not always obvious, since few of the more longstanding environmental treaties had prescribed a formal position on this issue. The CITES Secretariat has 'assumed' that it has the power to do $\mathrm{so}^{55}$ and there appears to have been little objection to this assertion. Convincing arguments have also been advanced as to the entitlement of MEAs to rely on the doctrine of implied powers, ${ }^{56}$ which would seemingly strengthen this assumption. Ultimately, while doubts have been raised as to whether this legal mandate legitimately resides in the CITES Secretariat or (as is more likely) within its $\mathrm{COP},{ }^{57}$ the practical utility of such agreements appears to outweigh any technical objections that might be expressed through a strict application of international treaty law.

In recent years, CITES has adopted a series of MOUs with allied institutions. The gestation of such instruments has not always been straightforward, especially in a marine context. The relationship between the trade convention and fisheries bodies, for instance, has been complicated by concerns that the listing of certain fish species on CITES - potentially at the instigation of parties far removed from its practical impact upon the fishery - may undermine the operation of carefully negotiated quotas and management principles. Indeed, the development of an MOU with the United Nations Food and Agriculture Organization (FAO) was particularly tortuous, requiring multiple drafts and ultimately entering into effect only with the concession of FAO involvement in the CITES listing process..$^{58}$ Previous attempts to cooperate with fisheries regulators had proved complicated in the context of Patagonian toothfish, with strong concerns raised over the implications of CITES involvement within CCAMLR. ${ }^{59}$ Beyond the marine sphere, however, CITES has successfully targeted a cooperative working relationship with the International Tropical Timber Organization, ${ }^{60}$ as well as fellow biodiversity treaties.

\footnotetext{
${ }^{54}$ For an appraisal of this trend in a biodiversity context, see $R$. Caddell, n. 4 above, at 62-68.

${ }^{55}$ Legal Personality of the Convention and the Secretariat (SC54 Doc. 8,2006$)$.

${ }^{56}$ See especially R. Churchill and G. Ulfstein, n. 3 above, at 655.

${ }^{57}$ See M.A. Young, n. 29 above, at 156-158.

${ }^{58}$ For a highly illuminating account of this issue and its practical and legal implications, see ibid., at 154-188.

${ }^{59}$ On this issue see L. Little and M. Orellana, 'Can CITES Play a Role in Solving the Problem of IUU Fishing? The Trouble with Patagonian Toothfish', 15:1 Colorado Journal of International Environmental Law and Policy (2004), 21. A truce was ultimately brokered with CCAMLR. See CITES Resolution Conf. 12.4, Cooperation between CITES and the Commission for the Conservation of Antarctic Marine Living Resources Regarding Trade in Toothfish (15 November 2002).

${ }^{60}$ CITES Resolution Conf. 14.4, Cooperation between CITES and
} ITTO Regarding Trade in Tropical Timber (15 June 2007). 
CITES remains committed to promoting collaborative working arrangements with appropriate multilateral bodies. In the context of biodiversity, the COP recently reiterated its faith in effective inter-treaty cooperation to enhance the coherent implementation of international commitments at a national level..$^{61}$ Likewise, as a key component of its Strategic Vision for the years 2008-2013, the COP undertook to 'contribute to significantly reducing the rate of biodiversity loss by ensuring that CITES and other multilateral instruments and processes are coherent and mutually supportive. ${ }^{62}$ To this end, Objective 3.5 of the CITES Strategic Vision calls upon the parties and Secretariat to cooperate 'as appropriate' with other relevant bodies dealing with natural resources 'in order to achieve a coherent and collaborative approach to species which can be endangered by unsustainable trade, including those which are commercially exploited'. In implementing this objective, CITES has identified a series of clusters through which cooperative efforts should be coordinated, including biodiversity-related and other nature conservation conventions, international environmental organizations, natural resources bodies, international trade and development organizations, international law enforcement agencies and international financial mechanisms. ${ }^{63}$ The pursuit of these objectives remains ongoing, with the fundamental components of the Strategic Vision recently extended to $2020 .{ }^{64}$ On biodiversity issues, cooperative work has been prioritized with the CBD and the CMS, to which this article now turns.

\section{COORDINATION BETWEEN THE CBD AND CITES}

The CBD remains the most widely ratified and thematically diverse of all MEAs adopted to date. Following a lengthy gestation under the United Nations umbrella, it was concluded at the UN Conference on Environment and Development in 1992. The CBD currently boasts 193 parties and, famously, one signatory, in the form of the United States. ${ }^{65}$ Operationally, the CBD bears little resemblance to CITES and the CMS. It contains no Appendices upon which particular species may be designated for priority activities. It instead operates on a more thematic basis, identifying cross-cutting issues upon which to foster multilateral cooperation. ${ }^{66}$ The

${ }^{61}$ CITES Resolution Conf. 16.4, Cooperation of CITES with Other Biodiversity-related Conventions (14 March 2013).

${ }^{62}$ CITES, Resolution Conf. 14.2, CITES Strategic Vision 2008-2013 (15 June 2007), Goal 3.

${ }^{63}$ Cooperation with Other Organizations - Overview (SC61 Doc. 15.1, 2011).

${ }^{64}$ CITES, Resolution Conf. 16.3, CITES Strategic Vision: 2008-2020 (14 March 2013).

${ }^{65}$ As of 3 June 2013.

${ }^{66}$ On the operation of the CBD generally, see M. Bowman, P. Davies and C. Redgwell, Lyster's International Wildlife Law (Cambridge University Press, 2011), at 587-628. On current operational directions,
CBD has, however, developed a strong institutional structure, encompassing a COP that is charged, inter alia, with developing 'appropriate forms of cooperation' with the executive bodies of similar bodies. ${ }^{67}$ The COP is supported by a proactive Secretariat, with a clear mandate 'to coordinate with other relevant bodies' ${ }^{68}$ and to represent the COP in establishing linkages at an executive level with allied regimes. ${ }^{69}$ Core technical institutions have also been established in the form of the Subsidiary Body of Scientific, Technical and Technological Advice (SBSTTA), alongside a Clearing-House Mechanism 'to promote and facilitate technical and scientific cooperation' ${ }^{70}$

The CBD is a lengthy document, establishing a broad framework to pursue its three core objectives, articulated in a rather unwieldy fashion as constituting

the conservation of biological diversity, the sustainable use of its components and the fair and equitable sharing of the benefits arising out of the utilization of genetic resources, including by appropriate access to genetic resources and by appropriate transfer of relevant technologies, taking into account all rights over those resources and to technologies, and by appropriate funding. ${ }^{71}$

In contrast, CITES is less ostensibly ecological in outlook and, beyond information-sharing and broad gestures of solidarity with other actors, has considered its role in addressing global environmental problems to be more tangential..$^{2}$ Interactions with the CBD have thus been framed in this context. As CITES exhibits fewer thematic overlaps with this regime than other CBD partners, synergy arrangements have largely advanced in a less formalized manner.

A productive working relationship was envisaged by both treaties at a preliminary stage. A Memorandum of Cooperation (MOC) was adopted in 1996, pledging institutional cooperation and information exchange, alongside the mooted coordination of work programmes (especially concerning reporting considerations) and encouraging joint conservation actions.

see E. Morgera and E. Tsioumani, 'Yesterday, Today and Tomorrow: Looking Afresh at the Convention on Biological Diversity', 21:1 Yearbook of International Environmental Law (2010), 3.

${ }^{67}$ CBD, n. 9 above, Article 23.4. Relationships with 'other international agreements, institutions and processes of relevance' have been a standing item of activity for the CBD since the first COP. See CBD Decision I/9, Medium-term Programme of Work of the Conference of the Parties (9 December 1994). The rationale for such arrangements has altered little since it was articulated at the second COP 'to avoid unnecessary duplication of activities and costs on the part of Parties and of the organs of the Convention'. CBD Decision II/13, Cooperation with Other Biodiversity-related Conventions (17 November 1995).

${ }^{68} \mathrm{CBD}$, n. 9 above. Article 24(d).

${ }^{69}$ Ibid., Article 23.4(h).

${ }^{70} \mathrm{lbid}$., Article 18.3.

${ }^{71}$ Ibid., Article 1.

72 Synergy with Biodiversity-related International Initiatives (CoP15 Doc.10.1, 2010), at 4. 
Shortly afterwards, CITES adopted a Resolution framing its relationship with the CBD in relatively vague terms, suggesting that parties streamline activities between national focal points and encouraging partnership opportunities between the conventions. ${ }^{73}$ In 2000 the MOC was amended to include an option to develop joint work plans 'from time to time'. Only one such initiative has been elaborated, encompassing the years 2000-2002. This involved cooperation on economic incentives, green labelling and sharing case studies, alongside more targeted action on plant conservation and bushmeat concerns.

Thus far, interactions between the CBD and CITES have proved comparatively limited in scope and outcome. Unlike the CMS and Ramsar Convention, CITES has not been formally appointed a 'lead partner' to the CBD on issues within its specialized focus, nor have any subsequent work plans been officially adopted. Nonetheless, important partnerships have been developed on an executive level, with CITES having been a core member of the CBD's Biodiversity Liaison Group (BLG) since its inception in 2004. ${ }^{74}$ The BLG provides a forum for executive staff to elaborate overarching policy priorities and identify further potential grounds for institutional synergies. Although hampered in the past by structural shortcomings,${ }^{75}$ considerable improvements have been made in recent years and the BLG provides a platform to foster a common ethos between its participants. Despite some initial reservations, ${ }^{76}$ CITES has orientated itself towards the pursuit of the overarching biodiversity loss goals adopted by the CBD. To this end, having pledged to 'contribute to significantly reducing the rate of biodiversity loss by ensuring that CITES and other multilateral instruments and processes are coherent and mutually supportive', ${ }^{77}$ its Strategic Vision was revised in the light of the 10th COP to the CBD, to work towards the reformulated Aichi targets. ${ }^{78}$ Although arguably inspired as much by the prospect of access to additional revenue streams through the Global

\footnotetext{
${ }^{73}$ CITES Resolution Conf. 10.4, Cooperation and Synergy with the Convention on Biological Diversity (20 June 1997). On the early scope for cooperation, see R. Cooney, 'CITES and the CBD: Tensions and Synergies', 10:3 Review of European Community and International Environmental Law (2001), 259.

${ }^{74}$ CBD Decision VII/26, Cooperation with Other Conventions and International Organizations and Initiatives (20 February 2004).

${ }^{75}$ On the operation of the BLG, see R. Caddell, n. 4 above, at 57-61. ${ }^{76}$ CITES has voiced concerns within the BLG over the general expectation to expend considerable resources in measuring performance towards what are effectively CBD priorities, which were formulated without the involvement of the other Secretariats. Report of the Fifth Meeting of the Liaison Group of Biodiversity-Related Conventions (BLG-5-Rep-Final, 14 September 2006) ('BLG-5 Report'), at 2; and Report of the Sixth Meeting of the Liaison Group of Biodiversityrelated Conventions, Document (BLG-6-Rep-Final, 31 May 2008), at 4 .

${ }^{77}$ CITES Resolution Conf. 14.2, n. 62 above, Goal 3.

${ }^{78}$ CITES Resolution Conf. 16.3, n. 64 above.

Environment Facility for future projects, this development has been warmly welcomed by the CBD parties ${ }^{79}$ and provides a unified objective between the Biodiversity-related Conventions in discharging their respective mandates. This may further bolster scientific cooperation, given that the work of the Chairs of the Scientific Advisory Boards of Biodiversity-related Conventions (CSAB), within which CITES is an active and valued participant, is intended to increasingly mirror that of the BLG, ${ }^{80}$ for which the pursuit of the Aichi targets remains a central objective.

Given its specific focus on regulating trade, the collaborative role of CITES is most commonly sought in a technical context. Since most MEAs lack effective compliance procedures and have limited enforcement roles, the experience of CITES is considered an invaluable guide by strategic partners in framing law enforcement policies and priorities. Although a number of effective partnership programmes have been developed, caution has nonetheless been advised in viewing CITES assistance as a panacea for enforcement concerns. Although sharing materials and examples of best practice are effective training tools to inform considerations on the ground, the very nature of law enforcement activities mean that proposed inter-treaty collaborations need to be clearly focused and involve personnel whose duties are engaged under both CITES and the partner regime. ${ }^{81}$ Considerable scope for effective collaboration to promote law enforcement activities is nonetheless provided by the International Consortium on Combating Wildlife Crime (ICCWC), within which CITES plays a key role. Established in 2010, the ICCWC has undertaken extensive advisory activities and has assisted in advancing wildlife crime provisions in a number of multilateral initiatives to date. Drawing on this expertise, the United Nations Office on Drugs and Crime has

${ }^{79}$ CBD Decision XI/6, Cooperation with Other Conventions, International Organizations and Initiatives (19 October 2012). The CBD had previously undertaken to strengthen administrative synergies with CITES 'to develop working arrangements that promote the coherent and mutually supportive implementation of the two conventions and their respective strategies'. CBD Decision X/20, Cooperation with Other Conventions and International Organizations and Initiatives (29 October 2010).

${ }^{80}$ Report of the Fourth Meeting of Chairs of Scientific Advisory Bodies of Biodiversity-related Conventions (UN Doc. UNEP/CBD/CSAB/4/2, 25 May 2011), at 9.

${ }^{81}$ Personal communication with John M. Sellar OBE, former Chief of Enforcement Assistance of CITES (on file with the author). Sellar cites the difficulties raised by coordinating training activities pursuant to the United Nations Environment Programme (UNEP) Green Customs initiative, where personnel based at ports would commonly encounter violations of international commitments concerning waste and dangerous cargoes, while those at airports were more likely to be faced with wildlife crime. Developing a homogenous approach to MEA compliance was therefore counter-productive. On the value of CITES enforcement experiences, see P.H. Sand, 'Enforcing CITES: The Rise and Fall of Trade Sanctions', 22:3 Review of European, Comparative and International Environmental Law (2013), 251. 
developed an analytic toolkit on forest crime,${ }^{82}$ which is likely to be used by a host of MEAs in framing implementation and enforcement policies in this context.

Forest considerations present clear opportunities for cooperation, with both conventions strongly engaged on this theme. CITES has sought policy synergies in respect of great apes, especially regarding in situ conservation, ${ }^{83}$ which may be pursued by CBD through its forest and protected areas strategies. Most tangibly, linkages have been formed to regulate the trade in bushmeat - a key concern for CITES for which it has pledged to cooperate with the CBD. ${ }^{84}$ In 2000, CITES established a Bushmeat Working Group, although progress was seemingly stymied by a lack of species designations on the CITES Appendices. In 2004, CITES identified poaching as 'the greatest threat' to the survival of a number of iconic species and called upon a number of bodies, including the CBD, to recognize their important supporting role in international conservation efforts. ${ }^{85}$ Meanwhile, having previously established its own Liaison Group on Bushmeat, ${ }^{86}$ a clear forum for inter-agency dialogue was established under the CBD, which has recently reiterated its desire to work closely with CITES..$^{87}$ In June 2011, the CBD Group organized a joint meeting with the Central African Bushmeat Working Group that had been established in 2004 by CITES, resulting in an extensive series of recommendations to be taken individually and in partnership to address bushmeat considerations. ${ }^{88}$ Significantly, these arrangements have provided a platform to re-energize the CITES Working Group - a stagnating forum that had failed to report to the Standing Committee in over three years. ${ }^{89}$

Specific cooperation between the two conventions is confined to a small number of issues of common concern. The CBD has consistently acknowledged the

82 United Nations Office on Drugs and Crime, Wildlife and Forest Crime Analytic Toolkit (United Nations, 2012).

${ }^{83}$ CITES Resolution Conf. 13.4, Conservation of and Trade in Great Apes (14 October 2004). As noted below, great ape conservation provides clear opportunities to collaborate with the CMS.

${ }^{84}$ CITES Decisions 14.73 and 14.74, Bushmeat (15 June 2007).

${ }^{85}$ CITES Resolution Conf. 13.11, Bushmeat (14 October 2004).

${ }^{86} \mathrm{CBD}$ Decision VI/22, Forest Biological Diversity (19 April 2002).

${ }^{87} \mathrm{CBD}$ Decision XI/25, Sustainable Use of Biodiversity: Bushmeat and Sustainable Wildlife Management (19 October 2012).

${ }^{88}$ Revised Recommendations of the Convention on Biological Diversity Liaison Group on Bushmeat in Report of the Eleventh Meeting of the Conference of the Parties of the Convention on Biological Diversity (UN Doc. UNEP/CBD/COP/11/35, 5 December 2012), at 238. 'Close cooperation' is required between the CBD and CITES in this regard. See ibid., Recommendation 16.

${ }^{89}$ Outcomes of the Joint Meeting of the CBD Liaison Group on Bushmeat and the CITES Central Africa Bushmeat Working Group (UN Doc. UNEP/CBD/LG-Bushmeat/2/4, 4 July 2011), at 4. need for collaborative practices on invasive species, ${ }^{90}$ while CITES has also sought to explore synergies in this regard. ${ }^{91}$ The CBD has recognized that: 'Parties should view their responsibilities for addressing invasive alien species not only from their perspective as importers, but also from their perspective as exporters. ${ }^{92}$ While fulfilling specific CBD commitments, ${ }^{93}$ this also clearly engages the work of CITES. In 2008, a mandate was established for an Inter-Agency Liaison Group on Invasive Alien Species, ${ }^{94}$ with the CITES Secretariat formally requested to join as part of its ongoing cooperation with the CBD. CITES has targeted improvements to its transportation policies ${ }^{95}$ and e-commerce practices as its key contribution to the Liaison Group in the immediate short-term. ${ }^{96}$ CITES was also identified as a key partner in addressing invasive species through its regulation of the trade in exotic pet animals. ${ }^{97}$ Again, the value of CITES in providing guidance on best practices concerning enforcement has been endorsed by the CBD in this context, which further considers that the implementation of CITES Resolution 13.10 by mutual parties 'will contribute to the implementation of Article 8(h)'.$^{98}$ Questions remain over the future role of CITES in this regard, however: at the most recent meeting of the Liaison Group, the Secretariat stated that it 'did not have a strong mandate' concerning this issue, but would remain supportive of this forum '[f]or the time being'. ${ }^{99}$

CITES is also deemed an important component in the CBD's Global Strategy for Plant Conservation (GSPC), with the MOC expressly revised to provide a more targeted remit for the trade convention. Following the

\footnotetext{
${ }^{90} \mathrm{CBD}$ Decision VI/23: Alien Species that Threaten Ecosystems, Habitats or Species (19 April 2002); CBD Decision VII/13, Alien Species that Threaten Ecosystems, Habitats or Species (Article 8 (h)) (20 February 2004).

${ }^{91}$ CITES Resolution Conf. 13.10, Trade in Alien Invasive Species (14 October 2004).

${ }_{92}$ Report of the Ad Hoc Technical Expert Group on Gaps and Inconsistencies in the International Regulatory Framework in Relation to Invasive Alien Species (UN Doc. UNEP/CBD/SBSTTA/11/INF/4, 17 June 2005), at 7.

${ }^{93}$ Especially CBD, n. 9 above, Article 3, which while guaranteeing the sovereign rights of parties to exploit their own resources establishes 'the responsibility to ensure that activities within their jurisdiction or control do not cause damage to the environment of other States or of areas beyond the limits of national jurisdiction'; and ibid., Article 8(h), which requires parties to 'prevent the introduction of, control or eradicate those alien species which threaten ecosystems, habitats or species'.

${ }^{94}$ CBD Decision IX/4, In-depth Review of Ongoing Work on Alien Species that Threaten Ecosystems, Habitats or Species (30 May 2008).

${ }^{95}$ CITES Decision 15.59, Transport of Live Specimens (25 March 2010).

${ }^{96}$ Report of the Second Meeting of the Inter-agency Liaison Group on Invasive Alien Species (UN Doc. UNEP/CBD/LG-IAS/2/3, 19 September 2011).

${ }^{97}$ CBD Decision X/38, Invasive Alien Species (29 October 2010).

${ }^{98}$ CBD Decision XI/28, Invasive Alien Species (19 October 2012).

${ }^{99}$ Report of the Third Meeting of the Inter-agency Liaison Group on Invasive Alien Species (UN Doc. UNEP/CBD/LG-IAS/3/2, 13 July 2012), at 2.
} 
expiry of the CBD-CITES work plan, the CITES Plants Committee has explored further synergies with the $\mathrm{CBD}$, establishing a working group to improve linkages with the GSPC. A mandate for further collaboration has been established, ${ }^{100}$ while the Plants Committee has framed its mid-term planning with reference to GSPC concerns, culminating in a revised list of activities to contribute to the CBD initiative during 2011-2020. ${ }^{101}$ This was endorsed at the most recent COP to CITES, which recognized 'the significant role that CITES can play in the achievement of the objectives and targets of the GSPC, and the effect upon CITES if the GSPC is successfully implemented'. ${ }^{102}$

Beyond these practical initiatives, synergy activities between the CBD and CITES are most likely to focus upon developing a more coordinated and cohesive implementation of multilateral commitments at the national level. The CBD has elaborated guiding principles for the sustainable use of biodiversity ${ }^{103}$ and, despite some initial reservations ${ }^{104}$ CITES has assisted in developing operational guidance for their implementation. ${ }^{105}$ Likewise, there is a degree of support among some mutual parties for closer alignment with CBDcentred access and benefit-sharing (ABS) issues within domestic CITES procedures, especially among developing States. While previous unilateral attempts to impose such criteria within national CITES permits were considered to be of dubious legality, ${ }^{106} \mathrm{ABS}$ considerations were raised as a draft resolution at the fifteenth COP. ${ }^{107}$ While ultimately defeated, this issue appears likely to be developed further at future COPs.

\footnotetext{
${ }^{100}$ Most recently through CITES Decision 15.91, Working Group on Mahogany and Other Neotropical Timber Species (25 March 2010).

${ }^{101}$ Cooperation with Advisory Bodies of other Biodiversity-related Multilateral Environmental Agreements (PC19 Doc.8.4, 2011), at Annex 1.

${ }^{102}$ CITES Resolution Conf. 16.5, Cooperation with the Global Strategy for Plant Conservation of the Convention on Biological Diversity (14 March 2013).

${ }^{103}$ Addis Ababa Principles and Guidelines for the Sustainable Use of Biodiversity; Annexed to CBD Decision VII/12, Sustainable Use (20 February 2004).

${ }^{104}$ The Animals and Plants Committees observed that it is 'evident' that the Principles 'are not always immediately applicable to the decision-making process under CITES', warning of 'possible complications' in using the socioeconomic basis of these Principles in no-detriment findings and that 'not all principles were of relevance' to the trade convention. CITES Resolution Conf. 13.2, Sustainable Use of Biodiversity: Addis Ababa Principles and Guidelines (14 October 2004), at Annex 2.

${ }^{105}$ CITES has developed an interactive CD-ROM addressing the implementation of the Addis Ababa Principles and Guidelines, which have been commended as a useful operational tool. See BLG-5 Report, n. 76 above, at 1.

${ }^{106} \mathrm{~F}$. Bloch, 'The "Brazilian Clause": A Recent Attempt to Create Linkages between the CBD and CITES', 10:3 Review of European Community and International Environmental Law (2001), 268, at 270. ${ }^{107}$ See further E. Morgera and E. Tsioumani, 'The Evolution of Benefit Sharing: Linking Biodiversity and Community Livelihoods', 19:2 Review of European Community and International Environmental Law (2010) 150, at 164-165.
}

Perhaps more significantly, and in line with the Aichi Targets, CITES has sought to improve synergies on a national level by assisting the parties in integrating complementary activities within the National Biodiversity Species Action Plans (NBSAPs) required under the CBD. ${ }^{108}$ Echoing a trend in CBD-CMS interactions, in May 2011 draft guidelines were commended to the parties, ${ }^{109}$ which will be trialled and developed further by the national Management Authorities in the coming triennium. The precise impact of this initiative, as well as the projected management commitments on the part of CITES, remain somewhat uncertain and the effect of such synergies is unlikely to be accurately quantifiable for some considerable time. Facilitating the alignment of multilateral commitments within national strategies arguably represents a more tangible and valuable form of inter-treaty cooperation than executive meetings and dialogues between sundry working groups, especially from the perspective of domestic nature conservation agencies that ultimately shoulder the main burden of treaty congestion. It should be observed however that, whatever the operational merits of this approach, its eventual successes are ultimately contingent upon the capacity, resources and competence of national bodies to facilitate such initiatives.

\section{COORDINATION BETWEEN THE CMS AND CITES}

Migratory species are acutely vulnerable to anthropogenic pressures and, due to their consistent and regular patterns of transboundary movements, are in particular need of multi-jurisdictional efforts to address their conservation status. As with CITES, the genesis of a 'broadly based convention' to promote the conservation and management needs of migratory species lay at the UNCHE. In June 1979 the CMS was duly concluded, entering into force in 1983.

The CMS advances a unique operational structure that, alongside prescribing general conservation policies for migratory species, also provides for the development of region- and species-specific subsidiary instruments under its auspices. ${ }^{110}$ Accession to these subsidiaries does not require membership of the CMS. These instruments may mirror the parent convention in

\footnotetext{
${ }^{108}$ CITES Notification to the Parties No. 2011/021, CITES and National Biodiversity Strategies and Action Plans under the Convention on Biological Diversity (24 February 2011).

109 CITES, Contributing to the Development, Review, Updating and Revision of National Biodiversity Strategies and Action Plans (NBSAPS): A Draft Guide for CITES Parties (CITES, 2011); CITES Notification to Parties No. 2011/026, CITES Parties and National Biodiversity Strategies and Action Plans under the Convention on Biological Diversity - A Draft Guide (4 May 2011).

110 On the structure and operation of the CMS generally, see M. Bowman, P. Davies and C. Redgwell, n. 66 above, 535-583; and R. Caddell, 'International Law and the Protection of Migratory Wildlife:
} 
formal structure or, as exemplified below in the context of saiga antelopes, are increasingly developed as nonbinding MOUs. The coordination of multilateral efforts to address migratory species therefore involves engagement with both the parent convention and an eclectic flock of self-contained subsidiaries. The governance of migratory species has traditionally extended well beyond the confines of the CMS regime, ${ }^{111}$ and numerous thematic partnerships with other MEAs and processes have been forged in recent years. ${ }^{112}$ CITES and the CMS have a long-established basis for interaction and have pursued a series of mutual activities in recent years. A host of species listed on the CITES Appendices have also received attention within the CMS. There is accordingly clear scope for both treaties to cooperate, both on a general level to improve institutional practices and, in specific contexts, to ensure effective coordination of conservation efforts regarding mutual species.

The CMS has consistently sought to improve linkages with 'existing wildlife conventions'. ${ }^{113}$ Strengthening institutional cooperation has also been a key consideration in current ${ }^{114}$ and ongoing strategic planning. ${ }^{115}$ Formal interactions date from 1999, when the CMS Scientific Council sought to establish 'close working cooperative arrangements on matters of common interest' with other technical bodies, inviting, inter alia, relevant CITES bodies to participate as permanent observers to

An Appraisal of Twenty-five Years of the Bonn Convention', 16:1 Colorado Journal of International Environmental Law and Policy (2005), 113, at 119-126.

111 See N. Matz, 'Chaos or Coherence? Implementing and Enforcing the Conservation on Migratory Species through Various Legal Instruments', 65:2 Zeitschrift für ausländisches öffentliches Recht und Völkerrecht (2005), 197.

112 On the scope for interactions between the CMS and CBD, see L. Glowka, 'Complementarities between the Convention on Migratory Species and the Convention on Biological Diversity', 3:3 Journal of International Wildlife Law and Policy (2000), 205. For an insightful appraisal of climate change synergy initiatives, see A. Trouwborst, 'Transboundary Wildlife Conservation in A Changing Climate: Adaptation of the Bonn Convention on Migratory Species and Its Daughter Instruments to Climate Change', 4:3 Diversity (2012), 258. On the relationship between the CMS and the EU, see R. Caddell, 'Biodiversity Loss and the Prospects for International Cooperation: EU Law and the Conservation of Migratory Species of Wild Animals', 8:1 Yearbook of European Environmental Law (2008), 218.

113 This was first advanced as an institutional priority in 1994. See CMS Resolution 4.4, Strategy for the Future Development of the Convention (11 June 1994).

114 CMS Resolution 8.2, CMS Strategic Plan 2006-2011 (25 November 2005). The Strategic Plan was later executively extended without amendment until the end of 2014.

115 CMS Resolution 10.5, CMS Strategic Plan 2015-2023 (25 November 2011). The maintenance of 'key partnerships and other supporting delivery frameworks, (including those of other Conventions)' is intended to continue as a core element in implementing the new Strategic Plan in due course. See CMS, The Strategic Plan for Migratory Species 2015-2023: Draft Skeleton for Consultation (April 2013), found at: <http://www.cites.org/eng/notif/2013/E-Notif-2013 $-015 A . p d f>$ its meetings. ${ }^{116}$ Relations between the two bodies were formalized through an MOU adopted in 2002, pledging to ensure policy compatibility, mutual representation at meetings, data exchange and a commitment to liaise annually to determine joint activities. This was clarified further by CITES in 2004, ${ }^{117}$ which identified an array of priority species for which conservation activities under both treaties should mutually reinforce. While a number of subsequent CMS instruments have expressly observed the value of CITES listing in future conservation initiatives, ${ }^{118}$ joint activities between the two bodies have centred on the cohort of species identified by CITES Resolution 13.3 - namely saiga antelopes, snow leopards, African elephants, marine turtles, whale and great white sharks and sturgeons.

A first suite of Joint Activities was agreed for 20052007, which focused on improving institutional practices and identifying commonalities in species coverage - an unexpectedly complicated task given increasingly apparent taxonomic and population discrepancies between the two conventions. A more targeted List of Joint Activities was developed for 2008-2010, subsequently extended into $2011^{119}$ and latterly to 2014. The current programme engages four broad areas of activity, including outreach and capacity building and administrative cooperation alongside, more tangibly, harmonizing nomenclature and joint activities for the species identified in CITES Resolution 13.3. The nomenclature project seeks to harmonize species coverage and taxonomic understanding between the two

\footnotetext{
${ }^{116}$ CMS Resolution 6.7, Institutional Arrangements: Scientific Council (16 November 1999).

117 CITES Resolution Conf. 13.3, Cooperation and Synergy with the Convention on the Conservation of Migratory Species of Wild Animals (CMS) (14 October 2004). The MOU is appended to the Resolution. ${ }^{118}$ See the preambles to the Memorandum of Understanding concerning Conservation Measures for Marine Turtles of the Atlantic Coast of Africa (Bonn, 1 July 1999; in force 1 July 1999) ('African Turtles MOU'); Memorandum of Understanding on the Conservation and Management of Marine Turtles and their Habitats of the Indian Ocean and South-East Asia (Manila, 23 June 2001; in force 1 September 2001) ('IOSEA'); Memorandum of Understanding concerning Conservation Measures for West African Populations of the African Elephant (Loxodonta africana) (Bonn, 22 November 2005; in force 22 November 2005) ('West-African Elephant MOU'); Memorandum of Understanding concerning Conservation, Restoration and Sustainable Use of the Saiga Antelope (Saiga spp.) (Bonn, 23 November 2005; in force 24 September 2006) ('Saiga MOU'); Memorandum of Understanding on the Conservation and Management of Dugongs (Dugong dugon) and their Habitats throughout their Range (Abu Dhabi, 31 October 2007; in force 31 October 2007); Memorandum of Understanding concerning the Conservation of the Manatee and Small Cetaceans of Western Africa and Macaronesia (Lomé, 3 October 2008; in force 3 October 2008); Memorandum of Understanding of the Conservation of Migratory Sharks (Manila, 12 February 2010; in force 1 March 2010) ('Migratory Sharks MOU'); and the Memorandum of Understanding between the Argentine Republic and the Republic of Chile on the Conservation of the South Andean Huemul (Plata del Mar, 4 December 2010; in force 4 December 2010).

119 Summary Record of the Fifty-ninth Meeting of the Standing Committee to CITES (SC59 Doc. 6, 2010), at 2-3.
} 
conventions - a problem first observed by CITES in $2000 .{ }^{120}$ Cooperative activities have been ongoing at a technical level, both between the two conventions and on a wider basis between the Biodiversity-related Conventions. Taking its lead from CITES, the CMS has adopted a list of standard nomenclature, ${ }^{121}$ with both conventions pledging continuing cooperation on this issue.

Most significantly, however, joint species activities have exemplified the scope for productive synergies between the two conventions. Interactions for snow leopard conservation have occurred primarily on a scientific basis, although the CMS has listed this species for Concerted Action, both individually ${ }^{122}$ and within its wider policies on Central Eurasian Aridlands. ${ }^{123}$ Support for further research activities on snow leopards has also been forthcoming under the CMS Small Grants Programme, most recently in April 2013 in Tajikistan with a view towards developing cross-border cooperation on both habitats and trade-related issues. ${ }^{124}$ CITES has also called for 'bold and innovative actions based on a sound base of information' for snow leopards. ${ }^{125}$ Future synergies would thereby appear to involve the CMS addressing habitat considerations, developing action plans and providing data within the context of its Central Eurasian Aridland Mammals Initiative, with CITES regulating trade and enforcement issues.

Synergies for marine turtle conservation have been relatively limited, although both CMS turtle subsidiaries clearly view CITES as a key partner in managing these species. ${ }^{126}$ Cooperative practices have been limited to encouraging parties to join CITES and implement these commitments effectively, while the trade convention has focused largely on freshwater turtles ${ }^{127}$ and interacted more ostensibly with the FAO. As far as

${ }^{120}$ CITES Resolution Conf. 12.11, Standard Nomenclature (15 November 2002)

${ }^{121}$ CMS Recommendation 9.4, Standardized Nomenclature for the CMS Appendices (5 December 2008).

${ }^{122}$ CMS Resolution 7.1, Concerted Actions for Appendix I Species (24 September 2002).

${ }^{123}$ CMS Recommendation 9.3, Tigers and Other Asian Big Cats (5 December 2008).

${ }^{124}$ CMS, 'Project of the Month: Supporting Tajikistan in Transboundary Cooperation on Snow Leopards' (1 April 2013), found at: <http://www.cms.int/news/PRESS/nwPR2013/04_apr/nw _020413_snowleopard.html>

${ }^{125}$ CITES Resolution Conf. 12.5, Conservation of and Trade in Tigers and Other Appendix-I Asian Big Cat Species (15 November 2002).

${ }^{126}$ Objective 5.1 of IOSEA, n. 118 above, requires parties to address trade concerns, which includes encouraging States to become parties to CITES and to facilitate better compliance with CITES through enhanced training, legislative improvements and effective monitoring programmes. The African Turtles MOU, n. 118 above, is less explicit, but has considered mutual participation by its signatories in other MEAs, expressly including CITES, to be a high priority. See ibid., Objective 4.3 of the Conservation Plan.

${ }^{127}$ CITES Resolution Conf. 11.9, Conservation of and Trade in Tortoises and Freshwater Turtles (20 April 2000). sturgeons are concerned, CITES has concentrated primarily on the caviar trade. CITES has, however, appealed for its parties to develop action plans and regional agreements for this species, ${ }^{128}$ for which the CMS would appear to be especially well placed to play a future supporting role. Likewise, efforts to conserve sharks under the CMS have long envisaged CITES involvement, ${ }^{129}$ with the Migratory Sharks MOU noting engagement with, inter alia, CITES as a 'fundamental principle'. ${ }^{130}$ CITES participated at the final drafting meeting for this instrument, which entered into force in 2010 and remains in its relative infancy, and has pledged cooperation for the three species of shark that are listed both under the trade convention and the MOU. Ultimately this may prove to be the most useful contribution by CITES in this respect, given that the trade in sharks appears to be predominantly localized and therefore lacks the international element required to formally trigger CITES obligations, as identified during joint discussions with the FAO. ${ }^{131}$ Nonetheless, the national institutions established pursuant to CITES provide an experienced and effective framework through which concerns over the domestic trade in shark products may be further addressed.

Thus far, examples of closest synergies from a species perspective can be seen in saiga and elephant initiatives. The saiga antelope is predominantly threatened by a combination of habitat erosion and lucrative poaching activities, which have long engaged the concerns of both conventions. The Saiga MOU, formalized by the CMS in 2006, envisages a central implementation role for CITES, noting that poaching and illegal trade are significant contributory factors in the decline of this species. Moreover, reporting requirements under the MOU are framed with specific reference to both CITES and the $\mathrm{CMS}^{132}$ - a unique position within CMS subsidiaries and one that clearly envisages future operational synergies. CITES has emphasized the need to implement the MOU and its work programme to its parties $^{133}$ and pledged to cooperate with the CMS on issues pertaining to the saiga antelope. ${ }^{134}$ Cooperation has indeed been a hallmark of the MOU's practices to date, with its two Meetings of the Signatories having been jointly organized and financed by the CMS and

\footnotetext{
${ }^{128}$ CITES Resolution Conf. 12.7, Conservation of and Trade in Sturgeons and Paddlefish (15 November 2002).

${ }^{129}$ CMS Resolution 8.16, Migratory Sharks (25 November 2005).

${ }^{130}$ Migratory Sharks MOU, n. 118 above, at Section 3. Such bodies are also invited to assist in the implementation of the MOU on the basis of their technical and administrative capacity. Ibid. at Section 6 . ${ }^{131}$ FAO, Report of the FAO/CITES Workshop to Review the Application and Effectiveness of International Regulatory Measures for the Conservation and Sustainable Use of Elasmobranchs (FAO, 2012), at 22 .

132 Saiga MOU, n. 118 above, at paragraph 6.

${ }^{133}$ CITES Decisions 14.91 and 14.93, Saiga Antelope (15 June 2007).

${ }^{134}$ CITES Decision 16.95, Saiga Antelope (Saiga tatarica) (14 March 2013).
} 
CITES, alongside a significant joint workshop convened in association with the Chinese CITES authorities. ${ }^{135}$

The Saiga MOU simultaneously demonstrates the benefits of close interactions between MEAs, as well as the difficulties encountered where the range of species addressed by one convention may not identically match those listed on another. Exemplifying the benefits of mutual priorities between treaties, Kazakhstan - a vital range State in multilateral efforts to promote saiga conservation - initially proved reluctant to accede to this instrument until a degree of pressure to this end was applied through CITES. ${ }^{136}$ Participation in the MOU subsequently appears to have inspired the Kazakh authorities to strengthen domestic legislation and to bolster anti-poaching activities. ${ }^{137}$ On the other hand, practical challenges to inter-treaty coordination swiftly became apparent, as the MOU reflected CMS designations at the material time and initially applied to only one of the two sub-species of saiga antelope, the Saiga tatarica tatarica. This marginalized Mongolia, a key habitat State and importer of saiga products, since the Saiga tatarica mongolica, which is native only to western Mongolia, was not covered by the MOU. ${ }^{138}$ The CITES Appendix II listing applied to the full range of saiga species, hence these discrepancies in scope threatened to undermine the MOU's operational consistency. In the meantime, Mongolia had been urged by CITES to implement aspects of the MOU that were relevant to the conservation of its saiga populations, but the CMS position nonetheless precluded it from full participation. ${ }^{139}$ In September 2010 the MOU was amended to incorporate the full range of saiga populations, integrating Mongolia more fully into the MOU and introducing greater coherence to cross-treaty efforts to protect this species. The new Mid-term International Work Programme for the Saiga Antelope therefore mandates a series of activities familiar to the work of both conventions and also offers opportunities in the longer-term to engage with CBD concerns, including commitments towards integrating saiga conservation plans into NBSAPs.

\footnotetext{
${ }^{135} \mathrm{CMS}$, Workshop on the Conservation and Sustainable Use of Saiga Antelope (29 September 2010), found at: <http://www.cms.int/ news/PRESS/nwPR2010/10_oct/Saiga_WorkShop_Urumqi_FINAL _REPORT_English.pdf>.

${ }^{136}$ Questionnaire submitted by the Saiga MOU to Phase One of the Working Group on the CMS Future Shape Process (on file with author).

${ }^{137}$ See R. Caddell, n. 4 above, at 66-67.

${ }^{138}$ Report of the Second Meeting of the Signatories to the Memorandum of Understanding concerning Conservation, Restoration and Sustainable Use of the Saiga Antelope (UN Doc. UNEP/CMS/SA-2/ REPORT, 2010), at 4.

139 CITES Decision 13:30, Saiga Antelope (12 October 2004; subsequently repealed). Concurrently, the CMS had recognized that 'similar measures to those foreseen for Saiga tatarica tatarica could be applied to Saiga tatarica mongolica, and invites Mongolia to consider applying them'. Extension of the Memorandum's Taxonomic and Geographical Scope (UN Doc. UNEP/CMS/SA-2/Doc/8, 25 August 2010), at 1.
}

Despite these promising initiatives, problems have been subsequently encountered in their implementation. At the sixteenth COP to CITES it was lamented that none of the range States to the Saiga MOU had submitted the required biennial reports. It was therefore not possible to assess progress towards meeting the objectives of this instrument, or identify where the core challenges to implementation may accordingly lie. ${ }^{140}$ Consequently, and with the CITES Secretariat lacking the mandate and resources to assess the progress of conservation initiatives, ${ }^{141}$ joint activities have instead been restricted to the sharing of CITES training manuals, broad commitments to applying the experience of law enforcement processes to assist in the monitoring of poaching and an undertaking to work with the CMS to source funding for the Third Meeting of the Signatories to the MOU. ${ }^{142}$ Beyond these activities, it appears that the primary role of CITES in addressing saiga concerns will be to reinforce national institutions, customs and law enforcement agencies within the countries concerned to address, inter alia, the trade in saiga derivatives on a domestic and transboundary basis.

Meanwhile, ongoing work to protect African elephants remains 'the major part of the two Conventions' collaboration'. ${ }^{143}$ Elephants have constituted the most iconic aspect of CITES activities to date, as well as an enduring source of friction across its faultlines of trade and conservation. In 2005, the CMS adopted an MOU on Western African Populations of the African Elephant, which recognized that implementing CITES commitments will form an integral part of conservation efforts under this instrument. ${ }^{144}$ CITES has established two leading systems to address elephant concerns Monitoring the Illegal Killing of Elephants (MIKE) and the Elephant Trade Information System (ETIS) which, while primarily focused on monitoring trade and hunting, also seek to support management and protection policies. ${ }^{145}$ These programmes generate substantial volumes of data that not only advance CITES objectives, but may also be harvested by other bodies, with the research regularly contributing to the work of other MEAs. ${ }^{146}$ Close cooperation has been envisaged with these CITES groups since the inception of the Elephant MOU. CITES-MIKE has agreed to act as a regional coordinator of the MOU's focal points, drawing on its previous experience and thereby preventing a costly duplication of administrative efforts within these

\footnotetext{
${ }^{140}$ Saiga Antelope (CoP 16 Doc. 56, 2013), at 3.

141 Ibid., at 3.

142 Ibid.

${ }^{143}$ Report of the Thirty-seventh Meeting of the Standing Committee to the CMS (CMS, 2010), at 13.

${ }^{144}$ West-African Elephant MOU, n. 118 above, preamble.

${ }^{145}$ CITES, Resolution Conf. 10.10, Trade in Elephant Species (25 November 2011).

${ }^{146}$ Personal communication with John M. Sellar OBE, n. 81 above.
} 
regions. ${ }^{147}$ Both Meetings of the Signatories convened to date have been attended by CITES-MIKE and have been followed immediately by joint meetings of the two bodies to ascertain future cooperation. A series of important allied policies have emerged from these meetings. In June 2008, a workshop organized by the CMS during the Pan-African CITES-MIKE Meeting resulted in a programme of activity for transboundary areas within a number of mutual parties, for which clear partnership roles for conservation efforts were established. ${ }^{148}$ Specific roles for both treaties are also demarcated within the MOU's Medium-term International Work Programme, while future areas of cooperation include broader conservation measures, continued attention to the transboundary activities programme and ongoing training of personnel. ${ }^{149}$

Future species-based cooperation appears likely to continue in the same vein, with CITES envisaging an expansion of joint activities to fur seals, dugongs and vicuña. ${ }^{150}$ The CMS Dugong MOU has identified a strategic role for CITES and interactions may therefore follow a similar model to the saiga and elephant programmes. Fur seals and vicuña are not as yet subject to distinct subsidiary instruments under the CMS, although they are frequently addressed by its Scientific Council. Cooperation with CITES is accordingly most likely to continue on a primarily technical basis, with the CMS monitoring of habitat-related considerations generating data that can provide a clearer basis to assess the impact of trade-related measures. In turn, the CMS has highlighted cetaceans as a key area of future cooperation with other actors, including a prominent role for CITES. ${ }^{151}$ A coordinated programme of activity is currently being developed for the mid-term future, which is intended to demarcate supervisory responsibilities and bring a degree of order to multilateral activities that have long been acutely affected by the challenges of treaty congestion.

Future species-based cooperation between CITES and the CMS is more ambiguous for two main reasons. First, their species overlap is deceptively limited, especially concerning species considered an operational priority under the CMS. This is particularly pronounced in the context of birds. The Agreement on the Conserva-

\footnotetext{
${ }^{147}$ MOU Coordination (UN Doc. UNEP/CMS/WAE2/Doc.7, 2011), at 3 .

${ }_{148}$ Workshop on the African Elephant (UN Doc. UNEP/CMS/WAE.1/ Inf.6, 19 March 2009), at 3.

${ }^{149}$ CMS, Second Joint Meeting of the CMS-MoU/CITES-MIKE, provisional agenda, found at: <http://www.cms.int/species/elephants/ MIKE_Meeting_docs/Niger_20June2011/Provisional_Agenda E.pdf>.

${ }_{150}$ Cooperation with Other Organisations: Convention on the Conservation of Migratory Species of Wild Animals (SC61 Doc. 15.4 (Rev. 1), 2011), at 2.

${ }^{151}$ CMS Resolution 10.15, Global Programme of Work for Cetaceans (25 November 2011)
}

tion of Albatrosses and Petrels, ${ }^{152}$ for instance, provides an express foundation for cooperation ${ }^{153}$ alongside deference to CITES in relation to the trade in eggs and derivatives ${ }^{154}$ yet ultimately there is little commonality in species coverage between the two instruments. Likewise, the African-Eurasian Waterbird Agreement, ${ }^{155}$ which applies to a vast range of species, would appear well placed to advance cooperative activities: the Secretariat is required to consult 'on a regular basis' with, inter alia, CITES, ${ }^{156}$ which has also been formally designated as one of the Agreement's Communication Partners ${ }^{157}$ while clear commitments are prescribed in respect of trade in endangered species. ${ }^{1{ }^{8}}$ However, only four AEWA species have been listed on CITES Appendix I ${ }^{159}$ with overlapping designations on Appendix II similarly limited. ${ }^{160}$ Avian cooperation could be developed further in the context of birds of prey, however there is substantial overlap between the falcons and owls listed on the CITES Appendices and the application of the MOU on Migratory Birds of Prey in Africa and Eurasia. ${ }^{161}$ There is a mandate to advance synergies with MEAs 'that achieve or otherwise assist the aims,

${ }^{152}$ Agreement on the Conservation of Albatrosses and Petrels (Cape Town, 2 February 2001; in force 1 February 2004) ('ACAP').

${ }^{153}$ The ACAP Secretariat is to liaise with other bodies 'whose activities are directly or indirectly relevant to the conservation, including the protection and management, of albatrosses and petrels', which would include CITES. Ibid., Article X(d).

${ }^{154}$ Under Paragraph 1.1.1 of the ACAP Action Plan, appended to the Agreement, and found at: <http://www.cms.int/species/acap/ acap_ap.htm>, parties are to prohibit trade in albatrosses and petrels without prejudice to any obligations they have under CITES. Exceptions to this prohibition are possible '[e]xcept for provisions made for species under CITES'. Ibid., Paragraph 1.1.2.

${ }^{155}$ African-Eurasian Waterbird Agreement (The Hague, 16 June 1995; in force 1 November 1999) ('AEWA').

${ }^{156} \mathrm{Ibid}$., Article IX. On the scope for inter-treaty cooperation through AEWA, see R. Adam, 'Waterbirds, the 2010 Biodiversity Target, and Beyond: AEWA's Contribution to Global Biodiversity Governance', 38:1 Environmental Law (2008), 87, at 112-129.

${ }^{157}$ G. Van Boven, AEWA Communication Strategy (AEWA, 2005), at 7 .

${ }^{158}$ Paragraph 2.1.1.(c) of the AEWA Action Plan, appended to the Agreement, found at: <http://www.unep-aewa.org/documents/ agreement_text/eng/2012-2015/aewa_agreement_text_2013_2015 _annex3_only.pdf>. Moreover, every State party to AEWA is also a member of CITES, following the recent Lebanese accession to the trade convention. The sole exception remains the EU which, while an active participant in AEWA, cannot currently accede to CITES.

${ }^{159}$ Namely the Slender-billed Curlew (Numenius tenuirostrus), Waldrapp (Geronticus eremite), Siberian Crane (Grus lecogeranus) and Dalmatian Penguin (Pelecanus crispus). The Slender-billed Curlew and Siberian Crane are also subject to distinct MOUs established under the auspices of the CMS.

${ }_{160}$ These species are the White-headed Duck (Oxyura leucocephelia), Comb Duck (Sarkidiornis melanotes), Shorebill (Balaeniceps rex), Black Stork (Ciconia nigra), Eurasian Spoonbill (Platalea leucorodia) and African Penguin (Splensiscus dermasus). Additionally all species of Flamingos are listed on CITES Appendix II; AEWA applies to the Greater Flamingo (Phocoenicopertus ruber) and Lesser Flamingo (Phocoenicopertus minor). The CMS has also established a distinct MOU on High Andean Flamingos.

${ }^{161}$ Memorandum of Understanding on Migratory Birds of Prey in Africa and Eurasia (Abu Dhabi, 22 October 2008; in force 1 November 2008). 
objectives and activities' with this $\mathrm{MOU},{ }^{162}$ alongside scope for CITES to be appointed a formal 'Cooperating Partner'. ${ }^{163}$ In the short-term, potential synergies will be seemingly focused on particular species of raptors. In January 2012, the CMS established a Sakar Falcon Task Force with the ultimate aim of developing a Global Action Plan and monitoring system for this species, with CITES accorded an opportunity to participate in this process.

Second, where such overlaps do exist, trade considerations may not ultimately provide a fertile source of cooperative activities. Trade in such species may be purely domestic and therefore not officially subject to CITES activity. Indeed, AEWA has conducted an extensive review of trade ${ }^{164}$ affecting the waterbirds under its purview, concluding that activities within the Agreement Area are overwhelmingly concentrated on a localized basis involving non-CITES species. ${ }^{165}$ Likewise, for mutual species, trade considerations may be a lesser priority for the CMS and its subsidiaries than other habitat-based threats. This is the case under ACAP, which has prioritized by-catch mitigation in its cooperative arrangements to date, ${ }^{166}$ while trade aspects have been given a lesser priority in the Single Species Action Plans elaborated under AEWA. ${ }^{167}$ Similarly, the trade in marine mammals is largely prohibited under other CMS subsidiaries, hence synergies with other bodies have been prioritized over CITES. Recent

162 Paragraph 6 of the MOU's Action Plan, appended to the MOU, found at: <http://www.cms.int/species/raptors/MoU_\&_AP/Eng/ Annex_3_Action_Plan_E.pdf .

163 Cooperating Partners (CMS/Raptors/MoS1/Doc.13.4, 28 November 2012), found at: <http://www.cms.int/species/raptors/MoS_Mtgs/ mos1_2012/doc_13_04_coop_partners_e.pdf >. The implications of Cooperating Partner status are, however, rather ambiguous: such actors 'may associate themselves' with the MOU, but there has been little further elaboration of this role.

164 'Trade' is not defined under AEWA and is seemingly interpreted as corresponding to domestic trade. This appears to be due to practical reasons - trade in AEWA species is essentially localized, while the requirement under AEWA, n. 155 above, Article IX, to liaise with CITES suggests that the trade convention is intended to act informally as a guide on international issues.

${ }^{165}$ AEWA, Review on Hunting and Trade Legislation in Countries Relating to the Species Listed in Annex 2 to the African-Eurasian Waterbird Agreement (AEWA, 2007), at 32-46.

${ }^{166}$ On the current state of cooperation between ACAP and other bodies, see ACAP, Development of Agreements with Other Organisations (MOP4 Doc. $15 \operatorname{Rev} 1,2012$ ). ACAP has prioritized the elaboration of MOUs and joint activities with regional fisheries management organisations - most notably CCAMLR. The proposed involvement of CITES in by-catch orientated collaborative arrangements has not generally been welcomed by fisheries actors. See R. Boardman, The International Politics of Bird Conservation: Biodiversity, Regionalism and Global Governance (Edward Elgar, 2006), at 195-199.

${ }^{167}$ For example, the Draft International Single Species Action Plan for the White-headed Duck (AEWA/MOP/3.22, 26 September 2005), found at: <http://www.unep-aewa.org/meetings/en/mop/mop3_docs/ pdf-docs/mop3_22_white_headed_duck_ssap.pdf>, at 59, considers trade to be a 'Medium Priority'. concerns over the transfer of a captive orca ${ }^{168}$ received minimal attention within the Agreement on the Conservation of Small Cetaceans of the Baltic, North-East Atlantic, Irish and North Seas 1992 (ASCOBANS), ${ }^{169}$ which appears poorly placed to consider trade issues. ${ }^{170}$ The transfer of cetaceans - which has provoked strong debate within CITES ${ }^{171}$ - has also been raised within the ACCOBAMS. ${ }^{172}$ The ACCOBAMS Scientific Committee has expressed concerns over the surreptitious replacement of deceased captive cetaceans with individuals from depleted wild stocks ${ }^{173}$ - an issue that was seemingly intended to have been brought before CITES at its recent COP. ${ }^{174}$ Likewise, despite a number of overlapping bat species, minimal attention has been given to trade considerations under EUROBATS. ${ }^{175}$ This issue notwithstanding, in many respects CITES has already made a strong contribution to conservation efforts under the CMS. Although interactions concerning particular species may be minimal - and even if the trade is exclusively domestic - the institutional machinery established and experience gained by national authorities in implementing their CITES commitments stand

\footnotetext{
${ }^{168}$ This incident involved the transfer of 'Morgan', a wild killer whale rescued in a poor physical condition and subsequently nursed back to full health, by one party (The Netherlands) to a non-party (Spain), although the legitimacy of this process has been strongly disputed. See A. Trouwborst, R. Caddell and E. Couzens, 'To Free or Not To Free: State Obligations and the Rescue and Release of Marine Mammals. A Case Study of "Morgan the Orca" ', 2:1 Transnational Environmental Law (2013), 117.

${ }^{169}$ Agreement on the Conservation of Small Cetaceans of the Baltic, North-East Atlantic, Irish and North Seas (Bonn, 17 March 1992; in force 29 March 1994).

170 See A. Trouwborst, R. Caddell and E. Couzens, n. 168 above, at 129-133.

${ }^{171}$ See S.J. Fisher and R.R. Reeves, 'Global Trade in Live Cetaceans: Implications for Conservation', 8:4 Journal of International Wildlife Law and Policy (2005), 315. In 2008, concerns over the trade in live specimens prompted an Israeli submission (later withdrawn) for the Solomon Islands population of Indo-Pacific bottlenose dolphins to be included in the CITES review of significant trade, to introduce stronger controls over exports from a population with a highly uncertain numerical and conservation status. See Selection of the Solomon Islands Population of Tursiops Aduncus for Inclusion in the Review of Significant Trade (AC23 Doc. 8.5.1, 19 April 2008). See further E.C.M. Parsons, N.A. Rose and T.M. Telecky, 'The Trade in Live Indo-Pacific Bottlenose Dolphins from Solomon Islands: A CITES Decision Implementation Case Study', 34:3 Marine Policy (2010), 384.

172 ACCOBAMS, n. 11 above.

${ }^{173}$ ACCOBAMS Recommendation SC 8.2, Recommendation Addressing the Continued Live Removals of Bottlenose Dolphins in the Black Sea (15 November 2012). See A. Trouwborst, R. Caddell and E. Couzens, n. 168 above, at 133-134.

174 This issue, largely confined to the Black Sea, should have been referred to the sixteenth COP to CITES, but the requisite documentation had not been prepared in time. See ACCOBAMS, Report of the Eighth Meeting of the ACCOBAMS Scientific Committee (ACCOBAMS, 2012), at 25-26. This issue could be pursued by the Council of Europe - a case file pursuant to the Convention on the Conservation of European Wildlife and Natural Habitats 1979 (Bern, 19 September 1979; in force 1 June 1982) is under consideration. ${ }^{175}$ Agreement on the Conservation of Populations of European Bats (London, 4 December 1991; in force 16 January 1994).
} 
them in good stead to address trade-related problems on the more localized level engaged under the CMS.

In the mid-term, the clearest examples of synergies between CITES and the CMS are likely to be technical in nature. The vast array of scientific groups established under the CMS and its subsidiaries generate considerable volumes of data that can support decision making within CITES. On a central level, the CMS has prioritized activities to address infectious diseases in the light of the $\mathrm{H}_{5} \mathrm{~N}_{1}$ Avian Influenza outbreak in 2005, which impacted heavily on migratory birds. In the light of effective inter-treaty cooperation to address Avian Influenza, ${ }^{176}$ the CMS-sponsored Scientific Task Force on Wildlife and Ecosystem Health was established to mitigate future mortality events, ${ }^{177}$ within which a prominent role is envisaged for CITES. ${ }^{178}$ This may lead to increased interaction with AEWA, which has acknowledged that the illegal trade and transportation of wild birds represents a significant means of spreading the $\mathrm{H}_{5} \mathrm{~N} 1$ virus. ${ }^{179} \mathrm{As}$ with the $\mathrm{CBD}$, the expertise of CITES in addressing non-native species has also been recognized. ${ }^{180} \mathrm{~A}$ mutually cooperative data-sharing arrangement is currently being fostered in the context of gorillas, with CITES having played an active part in the meetings of the Agreement on the Conservation of Gorillas and Their Habitats ${ }^{181}$ and viewing this instrument as a means of identifying the main jurisdictions through which the ICCWC ought to prioritize protective measures. Indeed, the MOU may assist in raising awareness of trade-related problems, which has been highlighted as a significant problem for law enforcement operations. ${ }^{182}$ CITES has also welcomed advice from the Gorilla Agreement in further developing law

\footnotetext{
${ }^{176}$ See R. Cromie et al., 'Responding to Emerging Challenges: Multilateral Environmental Agreements and Highly Pathogenic Avian Influenza H5N1', 14:3-4 Journal of International Wildlife Law and Policy (2011), 206.

177 CMS Resolution 10:22, Wildlife Disease and Migratory Species (25 November 2011). The Task Force was ultimately developed in unison with the FAO.

${ }^{178}$ CITES currently participates as a 'Partner', unlike the CBD, which is a 'Core Affiliate'. Birds remain the key concern within this forum, but a number of issues are of interest to CITES - not least the decimation of saiga antelope stocks through an outbreak of pasteurellosis in May 2010, while bushmeat concerns have also been identified as a Priority Area.

${ }_{179}$ AEWA Report of the Third Meeting of the Parties to AEWA (AEWA, 2005), 10. Mitigating the impact of the virus remains a core priority for AEWA, which has played a prominent role in synergy arrangements to address avian diseases in concert with the CMS and the Ramsar Convention. See R. Caddell, n. 4 above, at 67.

${ }^{180}$ AEWA, Report of the Fourth Meeting of the Parties to AEWA (AEWA, 2008), 20.

${ }^{181}$ Agreement on the Conservation of Gorillas and Their Habitats (Paris, 26 October 2007; in force 1 June 2008). As with AEWA, the Secretariat of the Gorilla Agreement is expressly required to consult, inter alia, with CITES, Ibid., Article IX(a). Likewise, under Article III.2(d), one of the key obligations prescribed under the agreement is to coordinate efforts to eradicate activities related to poaching.

182 See United Nations Office on Drugs and Crime, n. 82 above, at
} 165. enforcement training material $\mathrm{s}^{183}$ and, for its part, has a long history of cooperating with a variety of actors to address gorilla-related crime. $^{184}$ The possibility of CITES-MIKE being extended to gorillas has also been raised, amid concerns that budget limitations preclude the effective monitoring of habitats and law enforcement considerations under the CMS. ${ }^{185}$ Most tangibly, CITES is in a position to share examples of best practice and training on law enforcement issues, thereby assisting significantly with the practical implementation of the various CMS species initiatives on the ground. ${ }^{186}$ Accordingly, in implementing commitments towards data-sharing, the key practical challenge for intertreaty synergies involves marshalling the vast streams of data garnered under the auspices of the CMS to enable decisions on the impact of trade to be accurately taken within CITES, and for expertise on law enforcement and trade monitoring to be efficiently distributed within the various structures and subsidiaries of the CMS.

\section{CONCLUSIONS}

Inter-treaty cooperation remains a significant operational priority for virtually all MEAs in the mid- to longterm future. This is especially true in a biodiversity context, in which the normative landscape is one of multiple actors often seeking to address broadly similar issues of concern. CITES has actively engaged with allied biodiversity MEAs, most significantly with the CBD and CMS. To this end there have been a series of qualified successes. CITES has proved to be an invaluable source of technical advice and assistance on issues and species of common concern. Reciprocally, allied MEAs have furnished CITES with essential scientific data to assist in decision making under its structures. A degree of administrative streamlining is emerging, particularly in an African context and within initiatives that can scarcely afford the luxury of operative wastage. The precise role of CITES in particular projects has been more clearly demarcated. The participation of CITES in certain initiatives has raised the political visibility of individual species, which has also had a

\footnotetext{
${ }^{183}$ Report of the First Meeting of the Technical Committee (UN Doc. UNEP/CMS/GOR-TC1/Report, 2011), at 5.

${ }^{184}$ Personal communication with John M. Sellar OBE, n. 81 above.

${ }^{185}$ Report of the First Meeting of the Technical Committee, n. 183 above, at 4 .

${ }^{186}$ For instance, the essential role of CITES in this manner has been endorsed strongly by the Gorilla Agreement (which adopted Resolution 2.1, Cooperation and Information Sharing for Improved Wildlife Law Enforcement, 27 November 2011) and by the West-African Elephant MOU (according law enforcement capacity building a 'Very High' priority within its Medium Term International Work Programme concerning Conservation Measures for the West African Populations of the African Elephant (Loxodonta africana) 2012-2014 (UN Doc. UNEP/CMS/WAE2/Doc.8, 16 June 2011)).
} 
discernible effect upon regulatory attitudes on the ground. There has been a move towards facilitating a more effective streamlining of multilateral commitments at a national level. Perhaps most significantly, the national institutions established pursuant to CITES - and their experience in implementing the convention - offer a clear scope to address crime and trade issues advanced under other MEAs that lack the expertise to offer effective multilateral oversight of these concerns and where CITES obligations are not technically engaged.

Operative shortcomings have also been apparent, however. Although numerous points of mutual interest can be identified, active cooperation is either forthcoming or still at a preliminary or superficial stage. Synergies also tend to be most apparent at an executive level or between disembodied and disparate working groups. Species overlaps between CITES and allied MEAs are deceptively limited - and a laborious task to identify - which may render interaction with CITES a lower priority than other regimes. CITES has also proved to be a problematic partner in a marine context, with prospective suitors wary of the potential impact of species listings upon settled management measures and processes. Laudable attempts to improve national synergies remain fundamentally contingent upon the resources and coherence of domestic nature conservation structures. Likewise, wider problems of dovetailing disparate administrative processes, conservation priorities and institutional ethos between MEAs remain.
Inter-treaty synergy remains an attractive managerial mantra, not least in a straitened economic climate. Yet such cooperation remains deceptively expensive in terms of human and financial resources, especially given that many MEAs have experienced a net loss of staff in recent years and additional investment in monitoring such programmes - although necessary for their success - is not always an attractive proposition for parties ${ }^{187} \mathrm{As}$ pressure intensifies on MEAs to adopt closer working relationships with each other, the experience of CITES suggests that cooperative programmes that build clearly on the proven expertise and operational capacity of the partner on a limited range of species and themes seemingly presents the most effective model for treaty interaction in the biodiversity context.

Dr Richard Caddell is a Senior Lecturer in Law at Swansea University, where he is based at the Institute of International Shipping and Trade Law. He specializes in international maritime and environmental law, with a particular emphasis on wildlife protection and the conservation of marine biodiversity. He has advised numerous intergovernmental organizations, national governments and nongovernmental organizations on international and EU biodiversity law and is also an academic member of Francis Taylor Building, the United Kingdom's leading environmental law Chambers. The author is indebted to John M. Sellar OBE, Harro van Asselt and an anonymous reviewer for helpful comments and advice.

\footnotetext{
${ }^{187}$ States are, however, prepared to invest significantly on an ad hoc basis. For instance, France recently donated $€ 95,000$ to underwrite the costs of identifying future areas of synergy between CITES and the CBD. See Cooperation with Other Organisations: Convention on the Conservation of Migratory Species of Wild Animals (SC61 15.4 (Rev. 1), 2011), at 2.
} 